\title{
IMPROVEMENT OF CARBON-TO-NITROGEN (C/N) RATIO BY MAKING CASSAVA LEAF SILAGE AND ITS IMPLICATIONS IN DIGESTIBILITY IN GOAT
}

\author{
R. Noviadi, Zairiful, and A. A. Candra* \\ Department of Animal Husbandry, State Polytechnic of Lampung, Indonesia
}

\begin{abstract}
The study has been conducted in the laboratory and goats pen of the Department of Animal Husbandry, State Polytechnic of Lampung, Indonesia. The study lasted for six months with complete randomized design four treatments and six replications. A total of 24 local goats were used in this study. Treatment applied P1 $=$ Silase with $\mathrm{C} / \mathrm{N}$ ratio $17.88 ; \mathrm{P} 3=$ Silage with $\mathrm{C} / \mathrm{N}$ ratio 19.88; $\mathrm{P} 2=$ Silage with $\mathrm{C} / \mathrm{N}$ ratio 18.88 ; and $\mathrm{P} 4=$ Silage with $\mathrm{C} / \mathrm{N}$ ratio of 20.88 . The observed variables of physical quality, nutrition, and nutrient apparent digestibility of cassava leaves silage. The result was material composition with $\mathrm{C} / \mathrm{N}=$ 18,88 yielding physical characteristic of cassava leaves silage and the best nutrient apparent digestibility.
\end{abstract}

Keywords: $\mathrm{C} / \mathrm{N}$ ratio, cassava leaves silage, goat, apparent digestibility

\section{INTRODUCTION}

Silage-making process utilizes anaerobic bacteria from Lactobacillus class. These microorganisms are expected to grow rapidly resulting in lactic acid. The anaerobic microbial cell growth process is very complex, including the introduction of basic nutrients from the environment into cells, the conversion of nutrients to energy and various important constituents and breeding. Microbial growth can be characterized by an increase in the number and mass of cells, while the rate of growth depends on their physical and chemical environments (Silage-making process utilizes anaerobic bacteria from Lactobacillus class. These microorganisms are expected to grow rapidly resulting in lactic acid. The anaerobic microbial cell growth process is very complex, including the introduction of basic nutrients from the environment into cells, the conversion of nutrients to energy and various important constituents and breeding. Microbial growth can be characterized by an increase in the number and mass of cells, while the rate of growth depends on their physical and chemical environments (Manfaati, 2010).

All microorganisms require basic nutrients as a source of carbon, nitrogen, energy, and minerals. Nutritional components of both quantities and types are essential for microbial growth. Carbohydrates especially sugars are used as energy sources, other components containing carbon are peptides, amino acids, and organic acids. The use of carbon components as a source of energy by lactic acid bacteria is $70 \%$ for growth and $30 \%$ for metabolic processes. Carbon provides a source of energy and a mass-forming mass of microbial cells. Nitrogen is an important component for the constituents of proteins, nucleic acids, enzymes, and amino acids needed for growth and microbial metabolism processes (Jin Bo, 2005).

Elements of carbon and nitrogen are both needed as a source of energy for the growth of microorganisms. Therefore, the $\mathrm{C} / \mathrm{N}$ ratio ranging from 20 to 30 is the optimum level in anaerobic digestion process (Bayuseno, 2009). The element $\mathrm{C}$ in the ratio is seen as biodegradable carbon. A low $\mathrm{C} / \mathrm{N}$ ratio, or a high $\mathrm{N}$ content will increase emissions from nitrogen as ammonia. While the high $\mathrm{C} / \mathrm{N}$ ratio, or relatively low $\mathrm{C} / \mathrm{N}$ elemental content will cause the fermentation process to be slower as a result of decreased production of microbial and nitrogen enzymes into inhibiting factors (Supriyanto, 2006).

Carbon components in additive materials such as rice bran and corn flour as a substrate are energy sources and mass cell constituents that allow the growth and proliferation of lactic acid bacteria. Although rice bran and corn flour have high carbohydrate of 51.8\% (Tarmudji, 2004), but to support the growth and breeding of microbes should be added other compounds such as nitrogen source. Cassava leaves contain $21 \%$ crude protein that can be used as a source of nitrogen in a mixture of cassava leaves-grass silage-corn bran for the synthesis of anaerobic microbial protein. Nitrogen elements are necessary primarily for the formation of nitrogen-containing cells and metabolites such as protein, nucleic acid, amino acids, and enzymes (Frazer and Westhoff, 1988).

*Corresponding e-mail address: adicandra@polinela.ac.id

Copyright (C) 2017 Bangladesh Society for Veterinary Medicine

All rights reserved 0409/2017 


\section{R. Noviadi and others}

As previously explained that microbials require carbon and nitrogen elements for the benefit of the fermentation process in the optimal ratio. If anaerobic microbial nutrient needs are met then the growth will be more rapidly so that more and more lactic acid is formed. Increased lactic acid (organic acid) causes the anaerobic bacteria to die completely and the fermentation process is complete. This is very influential on the content of nutrients produced silage products. Anaerobic fermentation process that occurs in making cassava leaves silage with optimum $\mathrm{C} / \mathrm{N}$ ratio is expected to produce cassava leaves silage with good physical, chemical, and biological nutritional value.

This research is directed to improve the $\mathrm{C} / \mathrm{N}$ ratio of cassava leaves through the addition of rice bran and corn flour to be made silage and observed the physical quality, nutrition, and also the implication on the apparent digestibility of goats.

\section{MATERIALS AND METHODS}

The research has been carried out from March to August 2016 at the laboratory and goat pen of the Department of Animal Husbandry, Lampung State Polytechnic. The study was conducted in a complete randomized design with four treatments and six replications. A total of 24 local goats with average body weigh $21 \mathrm{~kg} \pm 583 \mathrm{~g}$ were used in this study. The treatment applied was $\mathrm{P} 1=$ Silage treatment with $\mathrm{C} / \mathrm{N}$ ratio 17.88; $\mathrm{P} 3=$ Silage with $\mathrm{C} / \mathrm{N}$ ratio 19.88; $\mathrm{P} 2=$ Silage with $\mathrm{C} / \mathrm{N}$ ratio 18.88; and $\mathrm{P} 4=$ Silage with $\mathrm{C} / \mathrm{N}$ ratio of 20.88 . The composition of cassava leaves silage substrate presented in Table 1. The calculation of C / N Ratio refers to the calculations of Richard and Nancy (1996).

$$
\begin{aligned}
& \mathrm{R}=\frac{\mathrm{Q} 1(\mathrm{C} 1 \times(100-\mathrm{M} 1)+\mathrm{Q} 2 \mathrm{~J}(\mathrm{C} 2 \times(100-\mathrm{M} 2)+\mathrm{Q} 3 \times(100-\mathrm{M} 3)}{\mathrm{Q} 1(\mathrm{~N} 1 \times(100-\mathrm{M} 1)+\mathrm{Q} 2(\mathrm{~N} 2 \times(100-\mathrm{M} 2)+\mathrm{Q} 3 \times(100-\mathrm{M} 3)} \\
& \text { Information: } \\
& \mathrm{R}=\mathrm{C} / \mathrm{N} \text { ratio } \quad \mathrm{N} 1=\text { Nitrogen from cassava leaves } \\
& \text { Q1 = Mass of cassava leaves }(\mathrm{kg}) \quad \mathrm{N} 2 \quad=\text { Nitrogen from rice brand } \\
& \mathrm{Q}=\text { Mass of rice brand }(\mathrm{kg}) \quad \mathrm{N} 3 \quad=\text { Nitrogen from corn meal } \\
& \text { Q3 = Mass of corn meal }(\mathrm{kg}) \quad \text { M1 = Moisture of cassava leaves } \\
& \text { C1 = Carbon from cassava leaves } \quad \text { M2 = Moisture of rice brand } \\
& \mathrm{C} 2=\text { Carbon from rice brand } \quad \text { M3 = Moisture of corn meal } \\
& \text { C3 = Carbon from corn meal }
\end{aligned}
$$

Table 1. The composition of cassava leaves silage substrate per $100 \mathrm{~kg}$

\begin{tabular}{lcccc}
\hline Ingredients & \multicolumn{4}{c}{ Treatments $(\mathrm{kg})$} \\
\cline { 2 - 5 } & $\mathrm{C} / \mathrm{N}=17.88$ & $\mathrm{C} / \mathrm{N}=18.88$ & $\mathrm{C} / \mathrm{N}=19.88$ & $\mathrm{C} / \mathrm{N}=20.88$ \\
\hline Cassava leaves & 100.0 & 88.5 & 78.1 & 66.0 \\
Corn meal & 0.0 & 0.2 & 1.4 & 6.8 \\
Rice bran & 0.0 & 10.8 & 20.0 & 26.7 \\
Molasses & 0.0 & 0.5 & 0.5 & 0.5 \\
Amount & 100.0 & 100.0 & 100.0 & 100.0 \\
\hline
\end{tabular}

The observed variables include physical (microscopic) qualities of cassava leaves silage product in accordance with the instructions of Syarifudin (2008) presented in Table 2 .

Table 2. Physical quality assessment of cassava leaves silage

\begin{tabular}{lccc}
\hline Physical Characters & \multicolumn{3}{c}{ Score } \\
\cline { 2 - 4 } & 3 & 2 & Rotten \\
\hline Smell & Acid & Not Aid & Black \\
color & Light brown & Dark brown & Much \\
Moldy & Not & Medium & Soft \\
Texture & Solid & Slightly & \\
\hline
\end{tabular}




\section{Observed variable:}

(1) The chemical nutrients include dry matter, crude protein, crude fat, crude fiber, Ash, Ca, and P.

(2) Biological nutritional values by apparent digestibility include dry matter, organic matter, crude protein, and crude fat in goats.

\section{Silage making process:}

(1) Cassava leaves are chopping with $3-5 \mathrm{~cm}$ then wilting at room temperature for 24 hours.

(2) Cassava leaves mixed with rice bran, corn meal, and molasses.

(3) The result of the mixture is inserted into the plastic and then the air inside the plastic is removed by using the vacuum cleaner, then the plastic is closed and tied with a rubber strap.

(4) Stays in a safe place for four weeks.

\section{RESULTS AND DISCUSSION}

Various C / N Ratio against characteristics of physical properties of silage

The observed results of various $\mathrm{C} / \mathrm{N}$ ratios on characteristics of silage physical properties are presented in table 3 .

Table 3. Various $\mathrm{C} / \mathrm{N}$ ratio to characteristic physical properties of silage

\begin{tabular}{lcccc}
\hline Treatment & \multicolumn{4}{c}{ Variables $(\mathrm{C} / \mathrm{N})$} \\
\cline { 2 - 5 } & $\mathrm{P} 0=17,88$ & $\mathrm{P} 1=18,88$ & $\mathrm{P} 2=19,88$ & $\mathrm{P} 3=20,88$ \\
\hline Smell & $2^{\mathrm{a}}$ & $3^{\mathrm{b}}$ & $3^{\mathrm{b}}$ & $3^{\mathrm{b}}$ \\
Color & $1^{\mathrm{a}}$ & $2^{\mathrm{b}}$ & $3^{\mathrm{c}}$ & $3^{\mathrm{c}}$ \\
Moldy & $3^{\mathrm{a}}$ & $3^{\mathrm{a}}$ & $3^{\mathrm{a}}$ & $3^{\mathrm{a}}$ \\
Texture & $1^{\mathrm{a}}$ & $2^{\mathrm{b}}$ & $3^{\mathrm{c}}$ & $3^{\mathrm{c}}$ \\
Dry matter(\%) & $51,33^{\mathrm{a}}$ & $79,00^{\mathrm{b}}$ & $73,17^{\mathrm{c}}$ & $74,33^{\mathrm{c}}$ \\
pH & $3,91^{\mathrm{a}}$ & $3,37^{\mathrm{b}}$ & $3,73 \mathrm{~b}^{\mathrm{a}}$ & $3,71^{\mathrm{b}}$ \\
Fleigh point & $49,49^{\mathrm{a}}$ & $71,58^{\mathrm{b}}$ & $57,20^{\mathrm{ac}}$ & $58,22^{\mathrm{c}}$ \\
\hline
\end{tabular}

Different superscripts on the same line showed significant differences $(\mathrm{P}<0.05)$

Table 3 shows that the various $\mathrm{C} / \mathrm{N}$ ratio of silage material has significant effect $(\mathrm{P}<0.05)$ on the physical quality of cassava leaves silage. The silage material with $\mathrm{C} / \mathrm{N}=18,88$ resulted in better physical quality of silage than other treatments. This can be seen from the lowest $\mathrm{pH}$ value and the highest Fleigh (NF) value. The likelihood of $\mathrm{pH}$ occurring at treatment $\mathrm{C} / \mathrm{N}=18.88$ was due to high lactic acid bacteria (LAB) activity with population of $1.7 \times 10^{9}$ (Table 4). This condition led to higher lactic acid concentration as a result of monosaccharide fermentation such as glucose and fructose performed by. According to Seglar (2003), lactic acid is the strongest acid among all the acids produced during the ensilase, making it more effective in lowering the $\mathrm{pH}$.

Table 4. Various $\mathrm{C} / \mathrm{N}$ ratio to lactic acid bacteria population

\begin{tabular}{lcccc}
\hline Treatment & \multicolumn{4}{c}{ Variables $(\mathrm{C} / \mathrm{N})$} \\
\cline { 2 - 5 } & $\mathrm{P} 0=17,88$ & $\mathrm{P} 1=18,88$ & $\mathrm{P} 2=19,88$ & $\mathrm{P} 3=20,88$ \\
\hline LAB $(\mathrm{cfu} / \mathrm{ml})$ & $1,58 \times 10^{9 \mathrm{a}}$ & $1,7 \times 10^{9 \mathrm{a}}$ & $1,33 \times 10^{9 \mathrm{a}}$ & $1.81 \times 10^{9 \mathrm{a}}$ \\
\hline
\end{tabular}

Different superscripts on the same line showed significant differences $(\mathrm{P}<0.05)$

The $\mathrm{pH}$ value of treatment $\mathrm{C} / \mathrm{N}=18.88 ; \mathrm{C} / \mathrm{N}=19.88$, and $\mathrm{C} / \mathrm{N}=20.88$ has an ideal range of 4.0--4.5 (Santoso et al., 2009). While the $\mathrm{C} / \mathrm{N}$ treatment $=17.88$ has the highest $\mathrm{pH}$ value. Chamberlain $\&$ Wilkinson (1996) states that if during primary fermentation lactic acid produced low concentration and no critical $\mathrm{pH}$ value (4.5), secondary fermentation will occur. 


\section{R. Noviadi and others}

The quality of silage can be seen from fleigh point. Fleigh point is characteristic index of silage fermentation based on dry matter value and $\mathrm{pH}$ of silage (Despal et al., 2011). Treatment $\mathrm{C} / \mathrm{N}=17.88$ has the lowest fleigh point $(\mathrm{P}<0.01)$, whereas $\mathrm{C} / \mathrm{N}=18.88$ has the highest value. Killic (1980) states that if the value of fleigh point $85--100$ states the quality of silage is very good, 60-80 is the value of fleigh point for good quality silage, while silage with fleigh point 55--60 value is classified rather well. Silage with fleigh point value at 25--40 intervals is of medium quality, if fleigh point $<20$ is considered very bad. Silage products of different $\mathrm{C} / \mathrm{N}$ ratios are presented in Figure 1.

$\mathrm{C} / \mathrm{N}=17,88$

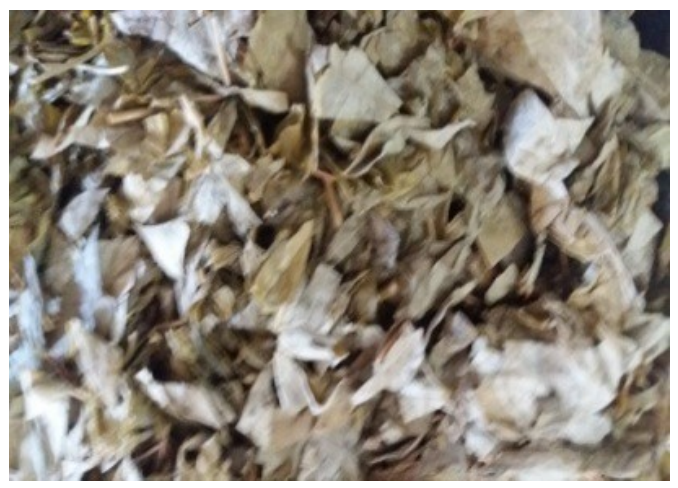

$\mathrm{C} / \mathrm{N}=19,88$

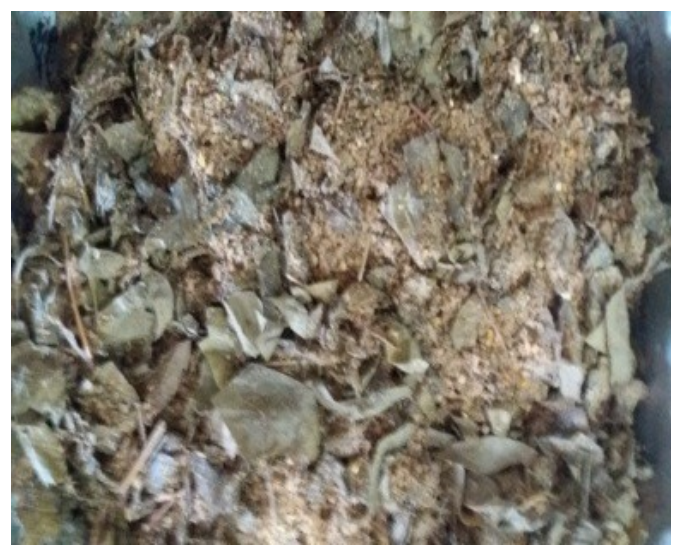

$\mathrm{C} / \mathrm{N}=18,88$

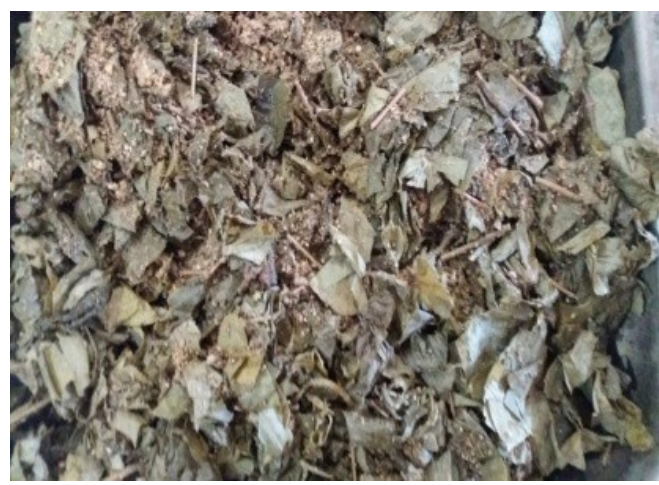

$\mathrm{C} / \mathrm{N}=20,88$

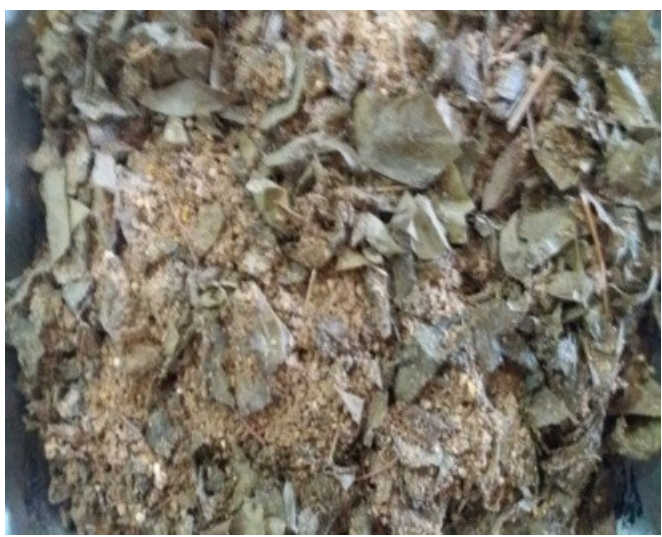

Figure 1. Silage of cassava leaves on different $\mathrm{C} / \mathrm{N}$ ratio

Various C / $\mathbf{N}$ Ratio against Chemical Characteristics of cassava leaf silage

The observed results of various $\mathrm{C} / \mathrm{N}$ ratios on chemical characteristics are presented in table 5 .

Table 5. Various $\mathrm{C} / \mathrm{N}$ ratio to the chemical characteristics of silage

\begin{tabular}{lcccc}
\hline Variables & \multicolumn{4}{c}{ Treatment (C/N) } \\
\cline { 2 - 4 } & $\mathrm{P} 0=17,88$ & $\mathrm{P} 1=18,88$ & $\mathrm{P} 2=19,88$ & $\mathrm{P} 3=20,88$ \\
\hline Crude protein (\%) & $24.73^{\mathrm{a}}$ & $19.13^{\mathrm{b}}$ & $17.97^{\mathrm{c}}$ & $18.32^{\mathrm{c}}$ \\
Crude fat (\%) & $2.47^{\mathrm{a}}$ & $7.12^{\mathrm{b}}$ & $5.55^{\mathrm{c}}$ & $6.93^{\mathrm{b}}$ \\
Crude fibre (\%) & $17.57^{\mathrm{a}}$ & $11.29^{\mathrm{b}}$ & $12.50^{\mathrm{b}}$ & $13.88^{\mathrm{c}}$ \\
Ash (\%) & $4.10^{\mathrm{a}}$ & $8.67^{\mathrm{b}}$ & $5.95^{\mathrm{c}}$ & $6.39^{\mathrm{c}}$ \\
\hline
\end{tabular}

Different superscripts on the same line showed significant differences $(\mathrm{P}<0.05)$ 
Improvement of carbon-to-nitrogen ratio by making cassava leaf silage

Table 5 shows that the variation of $\mathrm{C} / \mathrm{N}$ treatment ratio causes a very significant difference to the crude protein content of silage. This difference is due to the rate of use of each different feed material according to the formulation to obtain the desired $\mathrm{C} / \mathrm{N}$ ratio of the silage material. Consequently, each silage material contributes to different crude proteins. As a result the total content of crude protein silage differs between treatments. It also occurs in other nutrients.

\section{Various C / N Ratio Against Apparent Digestibility Coefficient of Nutrition in Goats}

The results of observation of various $\mathrm{C} / \mathrm{N}$ ratio to apparent digestibility coefficient of nutrition in goats is presented in table 6 .

Table 6. Various $\mathrm{C} / \mathrm{N}$ ratios to apparent digestibility nutrient on goats

\begin{tabular}{lcccc}
\hline Variables & \multicolumn{4}{c}{ Treatment $(\mathrm{C} / \mathrm{N})$} \\
\cline { 2 - 5 } & $\mathrm{P} 0=17,88$ & $\mathrm{P} 1=18,88$ & $\mathrm{P} 2=19,88$ & $\mathrm{P} 3=20,88$ \\
\hline Dry matter (\%) & $0.8173^{\mathrm{a}}$ & $0.9167^{\mathrm{b}}$ & $0.8642^{\mathrm{c}}$ & $0.8883^{\mathrm{d}}$ \\
Organic matter & $0.8431^{\mathrm{a}}$ & $0.9099^{\mathrm{b}}$ & $0.8697^{\mathrm{c}}$ & $0.9051^{\mathrm{b}}$ \\
Crude protein (\%) & $0.8634^{\mathrm{a}}$ & $0.9346^{\mathrm{b}}$ & $0.9383^{\mathrm{b}}$ & $0.9074^{\mathrm{c}}$ \\
Crude fat (\%) & $0.6712^{\mathrm{a}}$ & $0.9606^{\mathrm{b}}$ & $0.9643^{\mathrm{b}}$ & $0.9391^{\mathrm{c}}$ \\
\hline
\end{tabular}

Different superscripts on the same line showed significant differences $(\mathrm{P}<0.05)$

Table 6 shows that the presence of various $\mathrm{C} / \mathrm{N}$ ratio treatments led to very significant differences in nutrient apparent digestion coefficient. Treatment $\mathrm{P} 0(\mathrm{C} / \mathrm{N}=17.88)$ showed lower nutrient digestibility compared with other treatments. Treatment $\mathrm{P} 1(\mathrm{C} / \mathrm{N}=18,88)$ showed high performance of nutrient digestibility. The nutrient digestibility value of a feed material depends on several factors including livestock, age, feed, and nutrient content of feed, rough digestibility of raw protein, feed preparation (cutting, milling, and cooking), and the number of rations (Tillman et al. , 1991). Crude fiber is a major factor that affects the digestibility of nutrients. Treatment P0 ( $\mathrm{C} / \mathrm{N}=17,88)$ had the highest crude fiber content of $17.57 \%$ (Table 6). This results in lower nutrient digestibility compared with other treatments. Sutardi (1979) states that dry matter digestibility is influenced by feed protein content, because each protein source has different solubility and degradation resistance. The digestibility of organic matter is an important factor that can determine the value of feed. Each type of ruminant has rumen microbes with different abilities in degrading the ration, resulting in different digestibility. The rumen microbes are unable to digest the crude fiber components contained in the feed optimally. The crude fiber content in the feed will cause a low degradation, since crude fibers in the form of cellulose and hemicellulose often bind to lignin and will be difficult to break down by digestive enzymes (Tillman et al, 1998).

\section{CONCLUSIONS}

Various $\mathrm{C} / \mathrm{N}$ ratios in silage making yield different physical and chemical characteristics to cassava leaves silage product. The composition of the material with $\mathrm{C} / \mathrm{N}=18,88$ yields the best physical characteristics of cassava leaves silage. Cassava leaves meal silage by $\mathrm{C} / \mathrm{N}$ ratio $=18,88$ has the best value of apparent digestibility nutrients in goats.

\section{ACKNOWLEDGEMENTS}

To The Directorate of Research And Community Service, Directorate General of Research And Development Strengthening, Ministries of Research, Technology And Higher Education Republic Of Indonesia, for financial support.

\section{REFFERENCES}

1. Bayuseno and Athanasius P (2009). Application and testing of anaerobic digester technology model for waste processing of fruits from traditional markets. Rotation 11. 


\section{R. Noviadi and others}

2. Central Bureau of Statistics (2014). Provincial data with cassava cultivation land. http://www.bps.go.id/tnmn_pgn.php.

3. Borin K (2005). Cassava Foliage for Monogastric Animals. Swedish University of Agricultural Sciences. Uppsala.

4. Chamberlain AT and Wilkinson JM (1996). Feeding the Dairy Cow. Chalcombe Publications, Lincoln.

5. Coblenz W (2003). Principles of Silage Making. University of Arkansas. Payettevile.

6. Despal IG, Permana SN, Safarina and Tatra AJ (2011). Multiple usage sources of water-soluble carbohydrates to improve the quality of leaf silts Rami. Livestock Media 43: 69-76.

7. Frazer WC and Westhoff DC (1988). Food Microbiology. Mc. Graw-Hill Pub. Co. Ltd Book Inc. Westport. New York. P: 112.

8. Jin B, Yin P, Ma Y, Zhao L (2005). Production of lactic acid and fungal biomass by Rhizopus fungi from food processing waste streams. Journal of Industrial Microbiology \& Biotechnology 32: 678-686.

9. Khajarern $\mathrm{S}$ and Khajarern JM (2006). Use of cassava products in poultry feeding. http://www.fao.org/DOCREP/003/T0554E/T0554E10.htm.

10. Kilic A (1984). Silo yemi (Silage Feed). Bilgehan Press, Izmir.

11. Marhaeniyanto E (2010). Utilization of Cassava Leaf Silage for Goat Livestock Feed. Faculty of Animal Husbandry. University Tribuana Tungga Dewi.

12. Manfaati R (2010). Kinetics and optimum variables fermented lactic acid with mixed media tapioca flour and liquid waste tofu By Rhizopus Oryzae. Master Program in Chemical Engineering Diponegoro University. Semarang.

13. Martindah, Eny, Diwyanto and Kusuma (2007). Development of Integrated dairy cattle farming with bio-ethanol industry made from cassava. http://repository.ipb.ac.id/handle/123456789/41968.

14. McDonald P (1991). Biochemistry of silage. John Willey and Sons, Chichester. New York.

15. Noviadi R (2006). Effect of Dose And Incubation Time of Fermented Mixture of Cassava Flour Flour With Aspergillus Niger Against Changes in Nutrition, Metabolic Energy, Protein Digestibility And Broiler Performances. Thesis. University of Padjadjaran. Bandung.

16. Ravindran V and Rajaguru ASB (1988). Effect of stem pruning on cassava root yield and leaves growth. Sri Lankan Journal of Agricultural Science 25: 32-37.

17. Richard TL and Nancy MT (1996). C/N ratio. Science and Engineering. Cornell University. http://compost.css.cornell.edu/calc/rightmix.html.

18. Santoso BB, Hariadia TJ, Manikb H and Abubakar H (2009). Superior Grass Quality Tropical Ensilase Results with Lactic Acid Bacteria from Fermented Grass Extracts. Livestock Media 137-144.

19. Seglar B (2003). Fermentation analysis and silage quality testing. Proceeding of the Minnesota Dairy Health Conference College of Veterinary Medicine, University of Minnesota. p. 119-136.

20. Silalahi M and Suryani (2013). The Effect of Silage Giving Silage to the Increase of Daily Weight of Goat Livestock In Ngestirahayu Village, Punggur Sub-district, Central Lampung District. Lampung Agricultural Technology Assessment Institute.

21. Steel RGD and Torrie JH (1995). Principles and Procedures of Statistics, A Biometric Approach. PT Gramedia Pustaka Utama. Jakarta.

22. Suparjo (2010). Principles and factors influencing the making of silage. http//jatayu@66.com.

23. Supriyanto A (2006). Wastewater Sludge Application. PT Novartis Biochemie. http://wwwstd.ryu.titech.ac.jp/ indonesia/zoa/paper/html/paperAgusSupriyanto.html. 23 juni 2006.

24. Syarifuddin NA (2008). Characteristics and percentage of grass silage success elephants at various age cutting. Faculty of Agriculture Universitas Lambung Mangkurat, Banjarbaru.

25. Tarmudji (2004). Utilization of Onggok for Poultry Feed in Tabloid Sinar Tani, June 2004. http://www.litbang.deptan.go.id/artikel/one/71/pdf. 17 April 2006.

26. Tony S (2008). Preservation of Feed by Silage Making.

27. Widodo W (2010). Nutrition and Contextual Poultry Feed. 